\title{
Analysis of lung volume reduction surgery results with video-assisted thoracoscopic surgery in emphysematous lung patients
}

\author{
Tayfun Kermenli ${ }^{1}$, Cebrail Azar ${ }^{2}$ \\ ${ }^{1}$ Department of Thoracic Surgery, Istanbul Aydın University, Istanbul, Turkey \\ ${ }^{2}$ Department of Chest Diseases, Medicalpark Elazığ Hospital, Elazığ, Turkey
}

Kardiochir Torakochir Pol 2020; 17 (3): 127-131

\begin{abstract}
Aim: In our study, we aimed to evaluate the results of patients who underwent lung volume reduction surgery with videoassisted thoracoscopic surgery due to diffuse or upper lobe limited emphysema.

Material and methods: Patients who underwent lung volume reduction surgery (LVRS) for emphysema in our clinic between March 2015 and January 2020 were included in the study. The files of the patients were evaluated retrospectively. Age, gender, smoking history, hospitalization time, drain removal time, complications, and postoperative pulmonary function test values were evaluated in the patient records.

Results: Twenty-four of the patients were male and 2 were female. The average age was determined as 49.6. Twenty-six patients underwent 31 surgical procedures, 5 of which were bilateral. Twenty-seven of them were performed by videothoracoscopic LVRS. Preoperative mean forced expiratory volume in $1 \mathrm{~s}\left(\mathrm{FEV}_{1}\right)$ value was $32.7 \%$, total lung capacity $132 \%$, residual volume $280 \%$. The average length of hospital stay was found to be 7.75 days (4-19), and the time to remove the thorax drain was 9.5 (4-23) days. $\mathrm{FEV}_{1}: 1.78$ (48.5\%) was found in the pulmonary function tests of the patients at the $6^{\text {th }}$ month postoperative controls. According to preoperative $\mathrm{FEV}_{1}, 48.3 \%$ improvement was detected.

Conclusions: Volume reduction surgery is a treatment method that positively affects the natural course of emphysema in addition to quitting smoking and oxygen therapy. Patients with predominantly emphysema in the upper lobes, low exercise capacity, and appropriate $\mathrm{FEV}_{1}$ values benefited most from this treatment.
\end{abstract}

Key words: lung volume reduction, emphysematous, thoracoscopic, video-assisted thoracoscopic surgery.

\section{Introduction}

Chronic obstructive pulmonary disease (COPD) is a health problem with high morbidity and mortality worldwide [1]. In the case of emphysema, lung and alveolar tis-

\section{Streszczenie}

Cel pracy: W pracy poddano analizie wyniki operacji zmniejszenia objętości płuc wykonywanej z wykorzystaniem wideotorakoskopii u pacjentów z rozedmą uogólnioną lub ograniczoną do górnego płata płuca.

Materiat i metody: Do badania włączono pacjentów, u których przeprowadzono operacyjne zmniejszenie objętości płuc (LVRS) w naszej klinice od marca 2015 do stycznia 2020 r. Retrospektywnej analizie poddano dokumentację medyczną pacjentów. Analizowano następujące parametry: wiek, płeć, palenie tytoniu w wywiadzie, czas hospitalizacji, czas trwania drenażu, powikłania, a także pooperacyjne wyniki badań czynności płuc. Wyniki: Analizowana grupa obejmowała 24 mężczyzn i 2 kobiety. Średni wiek pacjentów wynosił 49,6 roku. U 26 pacjentów wykonano łącznie 31 zabiegów chirurgicznych (5 zabiegów obustronnych). W 27 przypadkach zabiegi LVRS wykonano z wykorzystaniem wideotorakoskopii. Przedoperacyjna średnia wymuszona objętość wydechowa w $1 \mathrm{~s} \mathrm{(FEV})$ wynosiła 32,7\%, całkowita pojemność płuc 132\%, a objętość resztkowa $280 \%$. Średni czas hospitalizacji wynosił 7,75 dnia (4-19), a czas drenażu klatki piersiowej 9,5 (4-23) dnia. W 6. miesiącu po operacji wartość FEV 1 w badaniach czynnościowych płuc wyniosła 1,78 (48,5\%). W porównaniu z przedoperacyjnymi wartościami $\mathrm{FEV}_{1}$ stwierdzono poprawę o 48,3\%.

Wnioski: Operacyjna redukcja objętości płuc, oprócz rzucenia palenia i tlenoterapii, jest metodą terapeutyczną, która korzystnie wpływa na naturalny przebieg rozedmy. Największe korzyści ze stosowania tej metody stwierdzono u chorych z rozedmą zlokalizowaną głównie w górnych płatach płuc, niską wydolnością wysiłkową i odpowiednimi wartościami $\mathrm{FEV}_{1}$.

Słowa kluczowe: zmniejszenie objętości płuc, rozedma płuc, torakoskopia, wideotorakoskopia.

sues are destroyed and as a result of hyperinflation dead cavities developing in the parenchyma. Hyperinflation is the main pathophysiological mechanism of pulmonary emphysema leading to dyspnea and poor quality of life [2].

Address for correspondence: Tayfun Kermenli MD, Department of Thoracic Surgery, Istanbul Aydın University, Istanbul, Turkey, phone: +90 4242348000, e-mail: tayfunkermenli@gmail.com

Received: 9.04.2020, accepted: 7.07.2020. 
The standard measure is for patients to quit smoking. As a medical treatment, inhaled long-acting bronchodilators, inhaled steroids, oral bronchodilators, pulmonary rehabilitation, optimal nutrition and vaccination are applied [3]. Lung volume reduction procedures are accepted as the gold standard treatment in patients where medical treatment is not sufficient and cannot provide optimal recovery [4].

Lung volume reduction surgery (LVRS) and bronchoscopic lung volume reduction (BLVR) using valves or coils are recommended by the Global Initiative for Obstructive Lung Disease (GOLD) [5]. The advantage of LVRS over medical treatment is more important in patients with upper lobe dominant emphysema and low exercise capacity after rehabilitation. On the other hand, lung volume reduction is reported to improve the quality of life in patients with advanced and heterogeneous emphysema [6].

LVRS, defined for the first time in 1957, was performed through a thoracotomy incision. It was defined as resection of the most emphysematous parts of the lung [7]. However, now lung volume reduction surgery is applied in a more minimally invasive manner with the development of video-assisted thoracoscopic surgery (VATS) methods. The most important reason for this is that VATS is used in many procedures including major lung resections in thoracic surgery operations. In addition, VATS provides a wide field of view in lung and mediastinal surgery $[8,9]$. With the use of a single port or multiple ports, patients have advantages over thoracotomy in terms of postoperative pain $[9,10]$. Since it has a lower postoperative pain rate, the time to return to daily life in patients undergoing LVRS is shortened. Although LVRS is more invasive than bronchoscopic lung volume reduction procedures, LVRS has been shown to reduce the risk of emphysema-induced mortality beyond symptomatic relief [11]. Both methods have advantages and disadvantages. Therefore, it is important to personalize the treatment in emphysema patients. When planning the treatment preference, evaluation of patients by a multidisciplinary team and taking the LVRS decision accordingly are recommended in many studies.

\section{Aim}

In our study, we aimed to evaluate the results of patients who underwent lung volume reduction surgery with VATS due to diffuse or upper lobe limited emphysema.

Table I. Selection criteria for lung volume reduction surgery

\begin{tabular}{|c|c|}
\hline Inclusion & Exclusion \\
\hline Stop smoking > 4 weeks & Continuing to smoke \\
\hline No comorbidity & Comorbid disease \\
\hline Heterogeneous emphysema on CT & Homogeneous emphysema on CT \\
\hline $\begin{array}{l}\mathrm{FEV}_{1}<45 \% \\
\mathrm{TLC}>100 \% \\
\mathrm{RV}>150 \% \\
\mathrm{RV} / \mathrm{TLC}>0.65 \\
\end{array}$ & $\mathrm{FEV}_{1}<20 \%$ \\
\hline $6-M W D>140 m$ & $\begin{array}{l}\text { Recurrent infectious } \\
\text { exacerbations }\end{array}$ \\
\hline
\end{tabular}

$\mathrm{CT}$ - computed tomography, $\mathrm{FEV}_{1}$ - forced expiratory volume in $1 \mathrm{~s}, \mathrm{RV}$ - residual volume, TLC - total lung capacity, 6-MWD - 6 min walking distance.

\section{Material and methods}

Twenty-six patients who underwent LVRS for emphysema in our clinic between March 2015 and January 2020 were included in the study. The files of the patients were evaluated retrospectively. In the patient records, age, gender, smoking history, hospitalization time, drain removal time, complications, preoperative and postoperative pulmonary function test values were recorded. Those with chronic comorbid diseases such as coronary artery disease, uncontrolled diabetes, or uncontrolled hypertension were not included in the study. Inclusion and exclusion criteria were determined in the study (Table I). Prior informed consent was obtained from all patients. Before the operation, all patients underwent bilateral chest radiography, thorax computed tomography (CT), and pulmonary function test. There was no DLCO test in our hospital, so patients could not be evaluated with this test.

The surgical procedure was started with VATS in all patients, but patients who continued with thoracotomy due to severe adhesion were excluded from the study. The lung tissue targeted for resection was decided by preoperative radiological evaluation and peroperative exploration. These lung areas were excised with a standard $60 \mathrm{~mm}$ endoscopic staple. At the end of the operation, 1 chest tube was routinely placed. Patients were routinely left to passive drainage by chest tube, but patients with excessive air leakage and an expansion defect on chest X-ray on the first postoperative day were subjected to negative aspiration. If the air leak after surgery continued for more than 7 days, it was considered as a prolonged air leak. The patients were routinely given mucolytic drugs and nebulization therapy. For pain control, non-steroidal anti-inflammatory agents and narcotic analgesia drugs were used when necessary. Perioperative prophylactic antibiotics were continued for at least 5 days or until the chest tube was removed. Pain of patients was determined by VAS scoring and recorded. In the postoperative period, patients were followed up with daily chest radiographs. When necessary, control was done with blood tests.

\section{Statistical analysis}

SPSS ver. 20.0 software (IBM Corporation, Armonk, NY, USA) was used to analyze data. Descriptive analysis was presented as means \pm standard deviations. Student's paired $t$-test was used for comparisons. The $p$-value considered statistically significant was $<0.05$.

\section{Results}

Twenty-four of the patients were male and 2 were female. The average age was determined as $49.6 \pm 16.4$ (32-68). Twenty-six patients underwent 31 surgical procedures, 5 of which were bilateral. Twenty-seven of them were performed by videothoracoscopic LVRS. Surgery could not be performed in 1 patient due to pleural adhesion, and this patient was excluded, and patients who underwent LVRS with thoracotomy were not included in the study. The average cigarette consumption in our patients was 36.1 packs/ year, but all patients quit smoking before the operation. 
Preoperative mean forced expiratory volume in $1 \mathrm{~s}\left(\mathrm{FEV}_{1}\right)$ value was 1.2 I and $32.7 \%$, total lung capacity (TLC) 8.6 I (132\%), residual volume (RV) 7.3 I (280\%). For the purpose of controlling air leakage during surgery, fibrin tissue adhesives were used in 11 (42.3\%) cases, bioabsorbable staple line reinforcement material was applied in $6(23 \%)$ cases, and leakage control was achieved with absorbable biomaterial cover in 7 (27\%) patients. The staple area was supported with pleural tents in $3(11.5 \%)$ patients, and apical pleural decortication was performed in 4 (15.3\%) patients. In patients who underwent pleural tents, the drain was placed over the pleural tent (Figure 1). The average length of hospital stay was found to be 7.75 days (4-19), and the time to removal the thorax drain was 9.5 (4-23) days. The demographic status of the patients and their perioperative findings are presented in Table II. Patients with excessive air leakage in the postoperative period were subjected to negative aspiration with $-20 \mathrm{~mm} \mathrm{H}_{2} \mathrm{O}$ following surgery.

Patients whose hospitalization was prolonged, lung expansion was not completed, but the air leak was reduced or not, they were discharged by installing a Heimlich valve in the thorax drain. The longest drainage period was found to be 23 days. Two patients underwent LVRS together with cancer surgery due to upper lobe originating squamous cell carcinoma (Figure 2). One of them was left upper lobectomy and the other was right upper lobectomy. The postoperative VAS score of the patients was found to be 2.7 on average.

In the early period, $53.8 \%$ of the patients developed complications; the most common complication was prolonged air leakage (9 patients, 34.6\%). Due to the prolonged air leak, 2 (7.7\%) patients underwent reoperation and air leak repair. Pneumonia (2 patients, $7.7 \%$ ) and atrial fibrillation (1 patient, 3.8\%) were observed (Table III). Mortality was not observed at the end of the first postoperative month; 1 (3.8\%) patient died at the 8th month due to pneumonia and COPD exacerbation. $\mathrm{FEV}_{1}: 1.78$ (48.5\%) was found in the pulmonary function tests of the patients at the $6^{\text {th }}$ month postoperative controls. According to preoperative $\mathrm{FEV}_{1}, 48.3 \%$ improvement was detected and this value was statistically significant $(p<0.05)$.

\section{Discussion}

Lung volume reduction surgery, as seen in our study, gives good results in suitable patients in the long term. Morbidity and mortality rates in patients are also low because it can be applied minimal invasively with videothoracoscopic surgery. In NETT, one of the important studies in the field of emphysema, patients eligible for surgery were shown to give better results in patients with $\mathrm{FEV}_{1}$, less than 45\%, TLC: higher than 100\%, RV: higher than 150\% [12]. In the same study, previous LVRS surgery, heterogeneous emphysema and pulmonary hypertension were accepted as exclusion criteria [12]. In our study, while selecting patients for surgery, NETT criteria were taken as the basis and surgery was planned for patients with $\mathrm{FEV}_{1}$ less than $45 \%$. The mean preoperative $\mathrm{FEV}_{1}$ value of the patients was $32.7 \%$. In the study of Ginsburg et al. [13] containing 90 patients, the

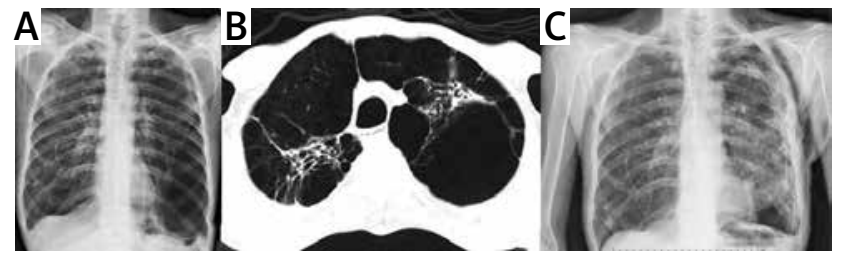

Figure 1. Preoperative chest X-ray (A) and thorax CT image (B) of the patient who underwent right LVRS 3 years ago. $\mathrm{C}$ - Postoperative chest $X$-ray of the same patient after left LVRS and pleural tents

Table II. Baseline demographics and perioperative results

\begin{tabular}{lcc} 
Patient characteristics & $N$ & $\%$ \\
Age, mean [years] & 49.6 & - \\
\hline Gender $(n=26):$ & & \\
\hline Male & 24 & 92.3 \\
\hline Female & 2 & 7.7 \\
\hline Side of VATS surgery $(n=27):$ & & \\
\hline Right & 15 & 55.5 \\
\hline Left & 7 & 26 \\
\hline Bilateral & 5 & 18.5 \\
\hline Fibrin glue & 11 & 42.3 \\
\hline Anti-air leakage biomaterial & 7 & 27 \\
\hline Bioabsorbable staple line reinforcement & 6 & 23 \\
\hline Pleural tent & 3 & 11.5 \\
\hline Apical pleural decortication & 4 & 15.3 \\
\hline Hospital stay, mean [days] & 7.75 & - \\
\hline Drain removal time, mean [days] & 9.5 & - \\
\hline
\end{tabular}

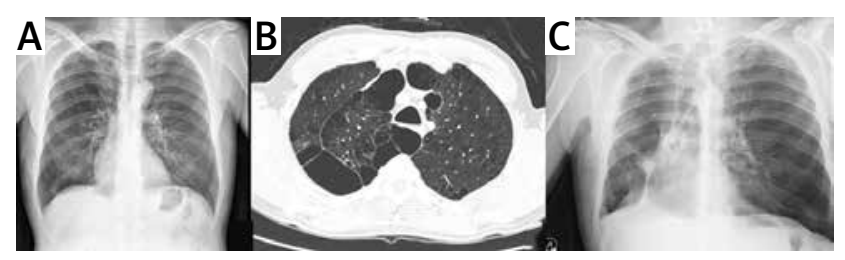

Figure 2. Images of the patient undergoing right upper lobectomy due to lung cancer and emphysematous lung disease, preoperative chest X-ray (A) and thorax CT (B), chest X-ray at the second postoperative month $(\mathrm{C})$

Table III. Postoperative complications $(n=14)$

\begin{tabular}{llc} 
Complications & N & $\%$ \\
Prolonged air leak & 9 & 34.6 \\
\hline Pneumonia & 2 & 7.7 \\
\hline Reoperation & 2 & 7.7 \\
\hline Atrial fibrillation & 1 & 3.8 \\
\hline
\end{tabular}

mean $\mathrm{FEV}_{1}$ value was reported to be $25.8 \%$, and we see that the results of our study are consistent with the literature.

In many reports in the literature, the rates of males and females are similar to each other in patients undergoing LVRS $[14,15]$. However, in our patient series, male patients accounted for $92.3 \%$ of our sample, and we think that this 
is due to the high rate of male smoking in our country. All of our patients were smokers, but all patients scheduled for surgery had stopped smoking at least 4 weeks before surgery. Medical mucolytic treatments were arranged, and respiratory physiotherapy was applied to the patients in the postoperative period, accompanied by a specialist physiotherapist.

There are many studies proving that the use of fibrin tissue adhesive prevents air leakage during lung resections [16]. The risk of air leakage is higher, especially after LVRS procedures that are surgically applied due to the emphysematous lung. In addition, long-term postoperative air leaks are associated with prolonged hospitalization times, increased hospital costs, and increased incidence of cardiopulmonary complications [17]. This increases the morbidity and mortality. Since we know this situation, fibrin tissue adhesives were used in 11 cases to prevent prolonged air leakage in patients with high risk of air leakage. Prolonged air leakage was observed in 9 patients in the postoperative period and only 2 of these patients were used with fibrin tissue adhesive. Of the eleven fibrin adhesives, 4 of them were used in combination with bioabsorbable staple line reinforcement material and 5 of them were combined with bioabsorbable cover, and no prolonged air leakage was observed in these patients.

In our study, bioabsorbable staple line reinforcement material was used in 6 patients (4 patients combined with fibrin glue) and no prolonged air leakage was observed in these patients. However, since there were not enough patients to compare, it was not determined whether it was statistically significant. It is known that the combined use of fibrin adhesive and staple line supporting materials is an effective air leak control method [17]. In the study of Murray et al. [17], it was observed that staple line supportive materials reduced the rate of air leakage. At high airway pressures, the ePTFE material has been reported to have a superior effect compared to the patch made of bovine pericardium. In their study on 66 patients undergoing lung resection, Thomas et al. [18] showed that staple line supportive material made from knitted calcium alginate prevented air leakage in $55 \%$ of patients. As a result of this phase 2 study, knitted calcium alginate bioabsorbable material has been reported to be ergonomic and safe [18]. This indicates that we need to do a randomized controlled study for prolonged air leakage.

Another air leak prevention method used during lung volume reduction surgery is pleural tent and pleural decortication $[19,20]$. It is known that with the application of pleural tenting after upper lobectomy/bilobectomy, the duration of intrapleural drainages and hospital stay is significantly reduced. It is a simple, safe and effective supplementary method in the prophylaxis of permanent alveolar air leakage and apical residual pleural space formation. In randomized controlled studies of Petrov et al. [21] including 40 patients, it was recommended that pleural tent application be applied prophylactically for alveolar air leakage control. In our series, pleural tents were applied in 3 of our patients, and pleural decortication in 4 of our patients. No fibrin glue or staple liner supportive biomaterial was used in these patients. However, prolonged air leakage was observed in one of our patients, and this patient was reoperated and air leak repair was performed.

Another interesting observation among our patients is that we have 2 patients who were followed up for a diagnosis of non-small cell lung cancer and underwent upper lobectomy. These patients are those in whom major lung resection is difficult due to the emphysematous lung. However, especially in patients with emphysema located in the upper lobe, it is a surgical advantage that the tumor is located in the upper lobe. The combination of major lung resection with LVRS provides an opportunity for selected patients with early-stage lung cancer and severe emphysema to undergo cancer resection rather than further reduction in pulmonary function. In these 2 patients, where we performed upper lobectomy (right upper and left upper lobectomy), no respiratory distress was observed in the postoperative period. Choong et al. [22] also recommend concomitant lung resection and LVRS surgery. In a study conducted by Caviezel et al. [23], it was reported that sublobar resections can be safely performed in such patients and it may be an alternative to radiotherapy.

The most common complication in almost all series after lung volume reduction surgery is air leakage. In our series, $34.6 \%$ prolonged air leakage was observed and a reoperation decision was taken in 2 patients. On the other hand, cardiac complications such as arrhythmia, myocardial infarction and pulmonary embolism after LVRS are similar to other thoracic surgery operations [24]. Arrhythmia is the most common cardiac complication after LVRS. In the NETT study, approximately $22 \%$ of patients developed postoperative arrhythmia requiring advanced medical treatment [25]. Myocardial infarction and pulmonary embolism rates have been reported as $1 \%$ and $0.8 \%$, respectively [26]. In our study, the postoperative atrial fibrillation rate was lower than that in the literature. We attribute this to both the low number of our patients and the good evaluation of the patients in the preoperative period.

The most important goal in emphysema surgery is to provide an acceptable improvement in the $\mathrm{FEV}_{1}$ value of patients after lung volume reduction. In our patients, an improvement of $48.3 \%$ was detected in the postoperative $6^{\text {th }}$ month measurements compared to the preoperative $\mathrm{FEV}_{1}$ values. This value was found statistically significant in Student's $t$ test $(p<0.001)$. This shows that it is possible to provide a good postoperative result after LVRS with appropriate patient selection. A decrease in lung volume with LVRS may improve quality of life with low postoperative mortality and acceptable morbidity. Another important point in these patients is quality postoperative care and respiratory physiotherapy support.

\section{Conclusions}

Lung volume reduction surgery increases the quality of life in patients when performed with VATS or bronchoscopi- 
cally. Which procedure will benefit the patients should be evaluated well in terms of surgical or bronchoscopic preferences due to their different anatomical patterns and concomitant diseases. Therefore, emphysema therapy should be individualized for each patient and managed by a team of experts. LVRS surgery can be preferred safely in patients with low morbidity and mortality values.

\section{Disclosure}

The authors report no conflict of interest.

\section{References}

1. GOLD. Global strategy for the diagnosis, management, and prevention of chronic obstructive pulmonary disease: 2018 report. 2018. https://goldcopd. org/wp-content/uploads/2017/11/GOLD-2018-v6.0-FINAL-revised-20-Nov_ WMS.pdf (accessed June 18, 2018)

2. Rossi A, Aisanov Z, Avdeev S, et al. Mechanisms, assessment and therapeutic implications of lung hyperinflation in COPD. Respir Med 2015; 109: 785-802.

3. O'Donnell DE. Hyperinflation, dyspnea, and exercise intolerance in chronic obstructive pulmonary disease. Proc Am Thorac Soc 2006; 3: 180-184.

4. Naunheim KS, Wood DE, Mohsenifar Z, et al. Long-term follow-up of patients receiving lung-volume-reduction surgery versus medical therapy for severe emphysema by the National Emphysema Treatment Trial Research Group. Ann Thorac Surg 2006; 82: 431-443.

5. Vogelmeier CF, Criner GJ, Martinez FJ. Global Strategy for the Diagnosis, Management, and Prevention of Chronic Obstructive Lung Disease, 2017 Report. GOLD Executive Summary. Am J Respir Crit Care Med 2017; 195: 557-582.

6. Seadler B, Thuppal S, Rizvi N, et al. Clinical and quality of life outcomes after lung volume reduction surgery. Ann Thorac Surg 2019; 108: 866-872.

7. Kemp SV, Polkey MI, Shah PL. The epidemiology, etiology, clinical features, and natural history of emphysema. Thorac Surg Clin 2009; 19: 149-158.

8. Kermenli T, Azar C. Evaluation of surgical procedures in primary mediastinal cysts and tumors: single-center experience. Kardiochir Torakochirur Pol 2019; 16: 109-113.

9. Erşen E, Kılıç B, Kara HV, et al. Uniportal versus multiport video-assisted thoracoscopic surgery for anatomical lung resections: a glance at a dilemma. Videosurgery Miniinv 2018; 13: 215-220.

10. Abu Akar F, Shaqqura B, Rumman N, Jiang L. Subxiphoid uniportal video assisted thoracoscopic lobectomy in a pediatric patient. Miniinvasive Surg 2020; 4: 10.
11. Martinez FJ, Han MK, Andrei AC, et al. Longitudinal change in the BODE index predicts mortality in severe emphysema. Am J Respir Crit Care Med 2008; 178: 491-499.

12. Criner GJ, Cordova F, Sternberg AL, Martinez FJ. The National Emphysema Treatment Trial (NETT) Part II: lessons learned about lung volume reduction surgery. Am J Respir Crit Care Med 2011; 184: 881-893.

13. Ginsburg ME, Thomashow BM, Bulman WA, et al. The safety, efficacy, and durability of lung-volume reduction surgery: a 10-year experience. J Thorac Cardiovasc Surg 2016; 151: 717-724.

14. Weder W, Tutic M, Lardinois D, et al. Persistent benefit from lung volume reduction surgery in patients with homogeneous emphysema. Ann Thorac Surg 2009; 87: 229-236.

15. Whittaker HR, Connell O, Campbell J, et al. Eligibility for lung volume reduction surgery in patients with COPD identified in a UK Primary Care Setting. Chest 2020; 157: 276-285.

16. Kawai N, Kawaguchi T, Suzuki S, et al. Low-voltage coagulation, polyglycolic acid sheets, and fibrin glue to control air leaks in lung surgery. Gen Thorac Cardiovasc Surg 2017; 65: 705-709.

17. Murray KD, Ho CH, Hsia JY, Little AG. The influence of pulmonary staple line reinforcement on air leaks. Chest 2002; 122: 2146-2149.

18. Thomas P, Massard G, Porte H, et al. A new bioabsorbable sleeve for lung staple-line reinforcement (FOREseal): report of a three-center phase II clinical trial. Eur J Cardiothorac Surg 2006; 29: 880-885.

19. Allama AM. Pleural tent for decreasing air leak following upper lobectomy: a prospective randomised trial. Eur J Cardiothorac Surg 2010; 38: 674-678.

20. Łochowski MP, Kozak J. Video-assisted thoracic surgery complications. Videosurgery Miniinv 2014; 9: 495-500.

21. Petrov D, Stanoev V, Manolov E, et al. Pleural tent after high partial lung resection--prospective randomised research. Khirurgiia 2003; 59: 11-14.

22. Choong CK, Mahesh B, Patterson GA, Cooper JD. Concomitant lung cancer resection and lung volume reduction surgery. Thorac Surg Clin 2009; 19: 209216.

23. Caviezel C, von Rotz J, Schneiter D, et al. Improved postoperative lung function after sublobar resection of non-small-cell lung cancer combined with lung volume reduction surgery in patients with advanced emphysema. J Thorac Dis 2018; 23: 2704-2710.

24. McKenna RJ Jr. Complications after lung volume reduction surgery. Chest Surg Clin N Am 2003; 13: 701-708.

25. Fishman A, Martinez F, Naunheim K, et al. A randomized trial comparing lung-volume-reduction surgery with medical therapy for severe emphysema. N Engl J Med 2003; 348: 2059-2073.

26. Lacour M, Caviezel C, Weder W, Schneiter D. Postoperative complications and management after lung volume reduction surgery. J Thorac Dis 2018; 23: $2775-2779$. 